\title{
Biochemical Properties of Catalase-positive Avian Haemophili
}

\author{
By P. J. BLACKALL \\ Department of Primary Industries, Animal Research Institute, Yeerongpilly 4105, Australia
}

(Received 11 March 1988; revised 25 May 1988)

\begin{abstract}
The biochemical properties of 39 strains of Haemophilus avium from chickens were determined. All the strains produced acid from fructose, galactose, glucose and mannose but not from lactose. Variable reactions were found for arabinose, maltose, mannitol, sorbitol, trehalose and xylose. No strains showed urease activity or produced indole, while $\beta$-galactosidase and/or ornithine decarboxylase activity was present in some strains. This variability allowed the recognition of 15 biochemical biovars including some not previously recognized in $H$. avium. Only $25(64 \%)$ of the $H$. avium strains could be assigned to the three species (Pasteurella avium, $P$. volantium and Pasteurella species A) recently proposed to replace $H$. avium.
\end{abstract}

\section{INTRODUCTION}

Haemophilic bacteria were first isolated from chickens in the 1930s when an upper respiratory tract disease of chickens, now known as infectious coryza, was associated with a bacterial agent originally named Bacillus haemoglobinophilus coryzae gallinarum (De Blieck, 1932). The aetiological agent of infectious coryza is now accepted as Haemophilus paragallinarum, an organism that requires $\mathrm{V}$-factor, but not $\mathrm{X}$-factor, for growth in vitro (Yamamoto, 1984). The earliest indication that more than one species of haemophilic organisms occurred in chickens was the work of McGaughey (1932), who reported that his 11 strains formed two groups on the basis of growth characteristics. Page (1962) also reported that his strains of avian haemophili formed two groups. One group was catalase-positive, capable of growth in air and did not cause disease in experimentally infected chickens. The second group was catalase-negative, would not grow in air and caused typical infectious coryza in experimentally infected chickens. Similar findings of catalase-positive, nonpathogenic strains and catalase-negative, pathogenic strains were reported by others (Roberts et al., 1964; Hinz, 1973; Rozanska, 1975). The nonpathogenic, catalase-positive strains were assigned to a new species, Haemophilus avium, by Hinz \& Kunjara (1977). Thus Bergey's Manual of Systematic Bacteriology lists two species of avian haemophili $-H$. paragallinarum, the causative agent of infectious coryza, and $H$. avium, widely regarded as a nonpathogenic commensal (Kilian \& Biberstein, 1984).

A subsequent DNA : DNA hybridization study demonstrated that in 18 strains of $H$. avium three DNA homology groups existed (Mutters et al., 1985). These three groups were genetically closer to Pasteurella multocida, the type species of the genus Pasteurella, than to $H$. influenzae, the type species of the genus Haemophilus (Mutters et al., 1985). Hence, it was proposed that the three homology groups be transferred to the genus Pasteurella as $P$. avium, $P$. volantium and an unnamed third group known as Pasteurella species A (Mutters et al., 1985).

In all the published studies on the catalase-positive avian haemophili small numbers of strains have been used. As an example, the description of the species H. avium (Hinz \& Kunjara, 1977) was based on 13 strains, while the proposal for the three new groups to replace $H$. avium (Mutters et al., 1985) was based on 18 strains. In the current study, the biochemical properties of 39 strains of $H$. avium are described. The correlation of these results with previous studies, particularly the proposal for the recognition of $P$. avium, $P$. volantium and Pasteurella species A (Mutters et al., 1985), is also described. 


\section{METHODS}

Strains. Of the 39 strains used in this study, 36 were obtained from Australian chickens. Dr R. Mutters (Institut für Medizinische Mikrobiologie, Marburg, FRG) provided the type strain of $P$. volantium (NCTC 3438) and the reference strain for Pasteurella species A (HIM 789-5). The type strain of H. avium (ATCC 29546) was obtained from the American Type Culture Collection (Rockville, Maryland, USA); ATCC 29546 is also the type strain for P. avium (Mutters et al., 1985).

Culture media. Test Medium agar, supplemented with chicken serum and NADH, termed TM/SN, was prepared as described previously (Reid \& Blackall, 1987) and used for the preparation of all inocula for biochemical tests. Other media used are described in the test procedure. All media were modified to contain $1 \%$ $(w / v) ~ \mathrm{NaCl}$. All incubations were at $37^{\circ} \mathrm{C}$. Solid media were incubated under increased $\mathrm{CO}_{2}$ tension $(5 \%)$, while broth media were incubated under aerobic conditions.

Carbohydrate fermentation. The ability of the strains to produce acid from a range of carbohydrates was tested using a previously described replica-plating technique (Blackall, 1983). The carbohydrates used were: Larabinose, D-fructose, D-galactose, D-glucose, D-lactose, maltose, D-mannitol, D-mannose, D-sorbitol, D-trehalose and D-xylose. Two grades of maltose were used, ultrapure and analytical. All other carbohydrates were analytical grade. The two grades of maltose were also used in a modified replica-plating technique, in which the fermentation test was done using a medium which did not contain chicken serum. All other fermentation tests were done in the presence of chicken serum.

Enzyme tests. Tests for indole production, $\beta$-galactosidase and urease activity were done as described by Cowan (1974), except that the test media were modified by the addition of $1 \%(v / v)$ heat-inactivated chicken serum and $0.0025 \%(\mathrm{w} / \mathrm{v}) \mathrm{NADH}$. Ornithine decarboxylase activity was tested for as described by Kilian \& Biberstein (1984). Urease activity was detected using $3 \mathrm{ml}$ slopes; all remaining tests were done in $0.5 \mathrm{ml}$ volumes. The tests were inoculated with a large loopful of growth from an overnight culture grown on TM/SN. The use of a small test volume and a heavy inoculum has been recommended for the genus Haemophilus (Kilian \& Biberstein, 1984).

Other tests. Tests for Gram stain reaction, catalase activity, ability to grow in air and requirement for X-and/or V-factor were done as described previously (Blackall \& Reid, 1982).

\section{RESULTS}

The 39 strains used in this study were all Gram-negative, capable of growth in air, required Vbut not X-factor, were catalase positive and urease negative, did not produce indole, and produced acid from fructose, galactose, glucose and mannose but not lactose. On the basis of these properties, all 39 strains were regarded as $H$. avium.

In the evaluation of the factors affecting the result of tests for acid production from maltose, it was found that the grade of maltose had no effect. However, the presence or absence of chicken serum did affect the result: in the presence of $1 \%$ chicken serum 26 cultures of $H$. avium produced acid, whereas in the absence of chicken serum only 15 isolates did so. The 11 organisms that produced acid only in the presence of chicken serum consisted of strains ATCC 29546 and HIM 789-5 and nine field isolates.

The strains of $H$. avium differed in $\beta$-galactosidase and ornithine decarboxylase activity and acid production from arabinose, maltose (tested in the absence of chicken serum), mannitol, sorbitol, trehalose and xylose. On the basis of this variation, 15 biochemicals biovars could be recognized (Table 1).

\section{DISCUSSION}

There is considerable disagreement in the literature over the ability of $H$. avium strains ATCC 29546 and HIM 789-5 to ferment maltose. Mutters et al. (1985) reported that neither strain produced acid from maltose. Hinz \& Kunjara (1977), who studied strains ATCC 29546 and HIM 789-5, and previous studies from this laboratory (Blackall \& Reid, 1982; Blackall, 1983), in which only strain ATCC 29546 was examined, reported the opposite. The results of the current study provide an explanation for this disagreement, as 11 isolates of $H$. avium, including strains ATCC 29546 and HIM 789-5, produced acid from maltose only in the presence of chicken serum. In the published studies recording that $H$. avium strains ATCC 29546 or HIM 789-5 produce acid from maltose (Hinz \& Kunjara, 1977; Blackall \& Reid, 1982; Blackall, 1983), the fermentation media used contained $1 \%(\mathrm{v} / \mathrm{v})$ chicken serum. In contrast, in the study 
Table 1. Biochemical biovars based on carbohydrate fermentation, $\beta$-galactosidase and ornithine decarboxylase $(O D C)$ activity in $39 \mathrm{H}$. avium strains

\begin{tabular}{|c|c|c|c|c|c|c|c|c|c|c|c|c|c|c|c|}
\hline $\begin{array}{r}\text { Biochemical biovar } \ldots \\
\text { No. of strains ... }\end{array}$ & $\begin{array}{c}\text { I } \\
(4)^{*}\end{array}$ & $\begin{array}{l}\text { II } \\
(1)\end{array}$ & $\begin{array}{l}\text { III } \\
(2)\end{array}$ & $\begin{array}{l}\text { IV } \\
\text { (3) }\end{array}$ & $\begin{array}{l}\mathrm{V} \\
(2)\end{array}$ & $\begin{array}{l}\text { VI } \\
(4) \dagger\end{array}$ & $\begin{array}{l}\text { VII } \\
\text { (1) }\end{array}$ & $\begin{array}{l}\text { VIII } \\
(2)\end{array}$ & $\begin{array}{l}\text { IX } \\
(2)\end{array}$ & $\begin{array}{l}X \\
(2)\end{array}$ & $\begin{array}{l}\mathrm{XI} \\
(1)\end{array}$ & $\underset{(12) \ddagger}{\text { XII }}$ & $\underset{(1)}{\text { XIII }}$ & $\begin{array}{c}\text { XIV } \\
(1)\end{array}$ & $\begin{array}{l}X V \\
(1)\end{array}$ \\
\hline \multicolumn{16}{|l|}{ Acid from: } \\
\hline Arabinose & - & - & - & - & - & - & - & - & - & - & - & + & + & + & + \\
\hline Maltose & - & - & - & - & + & + & + & + & + & + & + & - & + & - & - \\
\hline Mannitol & - & - & - & + & + & + & + & + & + & + & - & + & - & + & _ \\
\hline Sorbitol & - & - & - & - & + & - & - & - & - & + & - & - & - & - & - \\
\hline Trehalose & + & + & + & + & + & + & + & + & + & + & + & + & - & - & + \\
\hline Xylose & - & - & + & - & - & + & - & - & - & - & + & - & + & - & - \\
\hline$\beta$-Galactosidase & - & - & - & - & + & + & + & - & - & - & + & - & + & - & - \\
\hline ODC & - & + & - & - & - & - & - & - & + & - & + & - & - & - & \\
\hline
\end{tabular}

* Includes strain ATCC 29546. † Includes strain NCTC 3438. $\quad$ Includes strain HIM 789-5.

Table 2. Biochemical biovars of H. avium developed from the data of Mutters et al. (1985) and comparison with those established in this study

\begin{tabular}{|c|c|c|c|c|c|c|c|c|c|c|c|}
\hline \multirow[b]{2}{*}{ No. of strains ... } & \multicolumn{2}{|c|}{ P. avium } & \multicolumn{5}{|c|}{ P. volantium } & \multicolumn{4}{|c|}{ Pasteurella species A } \\
\hline & (1) & $\begin{array}{l}\text { II } \\
\text { (2) }\end{array}$ & $\begin{array}{c}\text { I } \\
(1)\end{array}$ & $\begin{array}{c}\text { II } \\
\text { (1) }\end{array}$ & $\begin{array}{l}\text { III } \\
\text { (4) }\end{array}$ & $\begin{array}{l}\text { IV } \\
\text { (2) }\end{array}$ & $\begin{array}{l}\mathrm{V} \\
(2)\end{array}$ & $\underset{(2)}{I}$ & $\begin{array}{l}\text { II } \\
\text { (1) }\end{array}$ & $\begin{array}{l}\text { III } \\
\text { (1) }\end{array}$ & $\begin{array}{l}\text { IV } \\
\text { (1) }\end{array}$ \\
\hline H. avium biovar* & I & III & - & V & VI & VII & - & XII & - & - & - \\
\hline e & - & - & - & - & - & - & - & + & + & + & + \\
\hline & - & - & + & + & + & + & + & - & - & + & + \\
\hline & - & - & + & + & + & + & + & + & + & - & - \\
\hline & - & - & + & + & - & - & + & - & - & - & - \\
\hline & + & + & + & + & + & + & + & + & + & + & + \\
\hline & - & + & + & - & + & - & - & - & + & + & - \\
\hline idase & - & - & + & + & + & + & + & - & + & - & + \\
\hline & - & - & - & - & - & - & + & - & - & - & - \\
\hline
\end{tabular}

* $H$. avium biovars II, IV, VIII, IX, X, XI, XIII, XIV and XV had no equivalent biovar.

† ODC, ornithine decarboxylase activity.

reporting that these strains did not produce acid from maltose (Mutters et al., 1985) the fermentation tests were done in the absence of chicken serum. It appears that chicken serum acts similarly to horse serum, which contains a maltase that converts maltose to glucose (Rogosa, 1974).

The production of acid from maltose is a key characteristic for defining the $H$. avium biovars established in this study, and also for the differentiation of P. avium, P. volantium and Pasteurella species A (Mutters et al., 1985). It is important that tests for this characteristic be performed in the absence of chicken serum. As chicken serum is not essential for the growth of $H$. avium (Blackall \& Reid, 1982), this requirement poses no practical problems.

The presence of chicken serum did not result in all the strains of $H$. avium producing acid from maltose. A total of 13 stains were negative for maltose fermentation, irrespective of the type of maltose or the presence or absence of chicken serum. The maltase presumably present in chicken serum may produce only a small amount of glucose. Hence, only some strains of $H$. avium may be able to produce detectable amounts of acid from this glucose.

H. avium strains ATCC 29546, NCTC 3438 and HIM 789-5 have been examined by others for their ability to ferment carbohydrates (Hinz \& Kunjara, 1977; Blackall \& Reid, 1982; Blackall, 1983; Mutters et al., 1985). These previous studies all reported the same pattern for these strains as was found in the current study, except for the already discussed maltose reaction. 
There has been no previous proposal for biochemical biovars within $H$. avium. Hence, no comparisons with previous studies are strictly possible. However, Mutters et al. (1985), who proposed the reorganization of $H$. avium, did publish information on the phenotypic properties of individual strains, allowing a biotyping scheme to be extracted (Table 2). A comparison between the results of Mutters et al. (1985) and the current study is also shown in Table 2. The comparison is considered valid for two reasons: $(a)$ the same biochemical tests were used in the two studies, and $(b)$ the three strains common to both studies (ATCC 29546, NCTC 3438, HIM 789-5) gave identical reactions in both studies.

The comparison shown in Table 2 raises several interesting points. While six of the H. avium biochemical biovars recognized in the present study had equivalents in those based on the data of Mutters et al. (1985), nine biovars had no equivalent. These nine biovars contained 14 strains. Thus, $36 \%$ of the strains possessed phenotypic property patterns not recognized by Mutters et al. (1985). In addition, five of the biovars based on the data extracted from Mutters et al. (1985) did not occur amongst the 39 strains examined here. These differences emphasize the heterogeneity of $H$. avium with respect to biochemical properties.

This heterogeneity made it impossible to assign all the $H$. avium strains of the present study to the new species, $P$. avium, $P$. volantium and Pasteurella species A, proposed by Mutters et al. (1985). A total of 25 of the 39 strains could be accommodated in the new species as follows: $H$. avium biochemical biovars I and III as $P$. avium; $H$. avium biochemical biovars V, VI and VII as $P$. volantium; and H. avium biochemical biovar XII as Pasteurella species A. However, there were problems in assigning the remaining biovars. One example is $H$. avium biovar IV. According to Mutters et al. (1985), $P$. avium is characterized by an inability to produce acid from mannitol, thus excluding $H$. avium biovar IV from this species. Yet the strains belonging to this biovar do not ferment arabinose and do not possess $\beta$-galactosidase activity, a combination that excludes them from $P$. volantium and Pasteurella species A and aligns them with $P$. avium. Another example is $H$. avium biovars VIII, IX and X, which possess properties characteristic of $P$. volantium but lack $\beta$-galactosidase activity. Mutters et al. (1985) state that $P$. volantium is characterized by this activity, thus excluding $H$. avium biovars VIII, IX and X from this species. This failure to assign many of the $H$. avium biovars to $P$. avium, $P$. volantium and Pasteurella species A reflects the fact that in describing these genomic groups, Mutters et al. (1985) were able to recognize only limited numbers of phenotypic properties (acid production from arabinose, maltose and mannitol and the presence or absence of $\beta$-galactosidase activity) that separated the new taxa. Hence, strains that show variation in one or two of these key characters cannot confidently be assigned to the new taxa.

While the published literature generally indicates that $H$. avium strains are nonpathogenic (Hinz \& Kunjara, 1977; Reid \& Blackall, 1984), some arabinose-fermenting strains of $H$. avium have caused clinical disease in experimentally infected chickens (Mutters et al., 1985). A total of 15 out of the 39 strains examined in this study were assigned to biovars characterized by an ability to produce acid from arabinose, indicating that studies on the pathogenic potential of these strains may be worthwhile.

In summary, this study has confirmed the biochemical heterogeneity of $H$. avium. Based on carbohydrate fermentation, ornithine decarboxylase and $\beta$-galactosidase activity, 15 biochemical biovars were defined amongst the $39 \mathrm{H}$. avium strains examined. Some of the biovars were characterized by property combinations not previously reported in $H$. avium. Further studies on the phenotypic and genotypic properties of $H$. avium, particularly those biovars that are not accommodated in the proposed new species of $P$. avium, P. volantium and Pasteurella species A, are required.

The technical assistance of Ms S. Brice is gratefully acknowledged. This work was supported in part by grants from the Australian Chicken Meat Research Council and the Australian Poultry Research Council. The assistance of my colleagues at this Institute, the Colin Blumer District Veterinary Laboratory (Armidale, Australia), Inghams Enterprises (Sydney, Australia), Mt Pleasant Laboratories (Launceston, Australia) and the Veterinary Research Institute (Melbourne, Australia) in providing some of the strains used in this study is gratefully acknowledged. 


\section{REFERENCES}

Blackall, P. J. (1983). An evaluation of methods for the detection of carbohydrate fermentation in avian Haemophilus species. Journal of Microbiological Methods 1, 275-281.

Blackall, P. J. \& ReID, G. G. (1982). Further characterization of Haemophilus paragallinarum and Haemophilus avium. Veterinary Microbiology 7, 359367.

Cowan, S. T. (1974). Cowan and Steel's Manual for the Identification of Medical Bacteria, 2nd edn. Cambridge: Cambridge University Press.

DE BliECK, L. (1932). A haemoglobinophilic bacterium as the cause of contagious catarrh of the fowl. Veterinary Journal 88, 9-13.

HiNZ, K.-H. (1973). Beitrag zur Differenzierung von Haemophilus-Stämmen aus Hühnern. I. Mitteilung: Kulturelle und biochemische Untersuchungen. Avian Pathology 2, 211-229.

HINZ, K.-H. \& KUNJARA, C. (1977). Haemophilus avium, a new species from chickens. International Journal of Systematic Bacteriology 27, 324-329.

Kilian, M. \& Biberstein, E. L. (1984). Genus II. Haemophilus. In Bergey's Manual of Systematic Bacteriology, vol. 1, pp. 558-569. Edited by N. R. Krieg. Baltimore: Williams \& Wilkins.

McGaughey, C. A. (1932). Organisms of the $B$. influenzae group in fowls. Journal of Comparative Pathology 45, 58-66.

Mutters, R., Piechulla, K., Hinz, H.-K. \& ManNHeIM, W. (1985). Pasteurella avium (Hinz and Kunjara 1977) comb. nov. and Pasteurella volantium sp. nov. International Journal of Systematic Bacteriology 35, 5-9.

Page, L. A. (1962). Haemophilus infection in chickens. I. Characteristics of 12 Haemophilus isolates recovered from diseased chickens. American Journal of Veterinary Research 23, 85-95.

Reid, G. G. \& Blackall, P. J. (1984). Pathogenicity of Australian isolates of Haemophilus paragallinarum and Haemophilus avium in chickens. Veterinary Microbiology 9, 77-82.

ReID, G. G. \& Blackall, P. J. (1987). Comparison of adjuvants for an inactivated infectious coryza vaccine. Avian Diseases 31, 59-63.

Roberts, D. H., Hanson, B. S. \& Timms, L. (1964). Observations in the incidence and significance of Haemophilus gallinarum in outbreaks of respiratory disease among poultry in Great Britain. Veterinary Record 76, 1512-1516.

Rogosa, M. (1974). Streptobacillus moniliformis and Spirillum minor. In Manual of Clinical Microbiology, 2nd edn, p. 330 . Edited by E. H. Lennette, E. H. Spaulding \& J. P. Truant. Washington: American Society for Microbiology.

RozansKa, M. (1975). Proby izolacji od kur i identyfikacji zarazka Haemophilus gallinarum. Medycyna weterynaryjna 31, 719-721.

Yamamoto, R. (1984). Infectious coryza. In Diseases of Poultry, 8th edn, pp. 178-186. Edited by M. S. Hofstad, H. J. Barnes, B. W. Calnek, W. M. Reid \& H. W. Yoder, Jr. Ames: Iowa State University Press. 